原著

\title{
MRI 上橋部高信号を示した10症例の神経耳科学的検討
}

\author{
吉田 晋也・斎藤雄一郎・濱田 敬永 \\ 渡辺 佳治・野村 泰之・辻 賢三
}

\section{Ten Cases of Pontine High Signal on MRI was Investigated by Neuro Otological Study}

\author{
Shinya Yoshida, Yuichiro Saito, Norihisa Hamada, \\ Yoshiharu Watanabe, Yasuyuki Nomura, Kenzo Tsuji \\ Department of Otolaryngology, Nihon University School of Medicine
}

Brain infarction on magnetic resonance imaging was defined with high signal on T2-weighted image and low signal on T1-weighted image. However, high signal on $\mathrm{T} 2$-weighted image and normal signal on $\mathrm{T} 1$-weighted image were frequently observed at the pons. Therefore, we investigated 10 cases of pontine high signal by neuro otological study. Four cases were regarded as pontine ischemia, but 5 cases were considered peripheral vestibular disorder and 1 case remained idiopathic because there were no abnormalities on neuro otological study.

In conclusion, neuro otological study was indispensable for the diagnosis of vertigo even when pontine signal was high.

Key words: high pontine signal, magnetic resonance imaging neuro otological study

\section{はじめに}

近年 MRI の普及によりめまい診断に拈ける後 頭蓋窩病変の検出率は飛躍的に向上した。しかし MRI 上の病変と神経耳科学的所見とが必ずしも 一致しない症例も認められる。

脳梗塞は MRI に扣いて T2 強調像で高信号 を，T1 強調像で低信号を呈するものと定義され ている。一方, 橋に拈いて T2 強調像で高信号を 呈するも，T1強調像にて異常を認めない症例 (以下橋部高信号) もしばしば認められる。この ような症例では一過性の平衡障害を示す症例が多 いと報告されている1) が，神経耳科学的に検討す るとめまいの原因としては橋の虚血によるものば

日本大学医学部耳鼻咽喉科学教室
かりでなく，末梢前庭障害によるものも認められ る。今回めまいを主訴とし MRI 上橋に高信号を 呈した症例について神経耳科学的所見との関連性 について検討した。

$$
\text { 対 象 }
$$

1997年 1 月から 12 月の間に日大板橋病院耳鼻咽 喉科神経耳科外来を受診し, 神経耳科学的検査及 びMRI を施行した症例を対象とした。その中で MRI 上橋部高信号を呈した 10 症例について検討 した。な特対象とした症例は神経耳科学的検查に て中枢性の病変が疑われた症例及び他院, 他科に てMRI を施行し当科に精査目的にて紹介された 症例である。

\section{結果}

10 症例の平均年齢は67.1歳（男性 4 例，女性 6 
例）であり，主訴は自発性回転性めまい 5 例，頭 位性めまい 4 例, 浮動感 1 例であった。合併症と して高血圧は 8 例, 糖尿病（境界型は含めず）は 2 例に認められた。MRI 上の橋の高信号は両側 性 8 例, 片側性 2 例であり, 全例とも辺縁が不明 瞭であった。テント上虚血性病変として大脳基底 核, 視床の皮質下高信号の合併は 9 例に認められ た。神経耳科学的検査により橋の虚血が原因と考 えられた中枢性の症例は 4 例であり, 初診時眼振 所見では方向交代性上行性頭位眼振が 2 例, 注視 方向性眼振が 1 例, 下眼瞼向き頭位变換眼振が 1 例であった。視標追跡検査（ETT）では全例に saccadic pursuit 認めた。視運動性眼振検査 (OKP) では 3 例に緩徐相速度の低下及び眼振頻 度の低下を, 1 例に眼振解発の左右差を認めた。

一方，末梢前庭障害と考兄られた 5 例の眼振所 見は方向固定性頭位眼振が 2 例, 方向交代性下行 性頭位眼振が 2 例, 水平回旋混合性自発眼振が 1 例であった。視標追跡検査（ETT）では全例と も smooth pursuit であった。視運動性眼振検査 (OKP) では 3 例の眼振解発は良好であったが, 2 例に患側向き OKP での緩徐相速度の低下がみ られた。温度眼振検査では 4 例に一側性の反応低 下 (CP) が認められた。CP の判定基準は最大緩 徐相速度に $20 \%$ 以上の差を認めたもの及び $10^{\circ}$ /s 以下のものとした。

な拉 1 例（症例 No. 8）は神経耳科学的検査に
て異常所見がなく病変が特定できなかった（表 1 )。

以下代表的な 2 症例について述べる。 症例 No. 6, 68歳 女性

主訴 回転性めまい

既往歴 高血圧にて降圧剂服用中

現病歴 平成 8 年 12 月 29 日起床時立ち上がった 際に回転性めまいが出現し，約10分間持続した。 嘔気, 嘔吐を伴うも蝸牛症状はなかった。以後頭 位変換時の浮動感が持続するため, 平成 9 年 1 月 14 日当科受診となる。

経過 初診時自発眼振はないも，方向交代性上 行性頭位眼振を認め，減衰はみられなかった（図 1)。また脳神経症状・小脳症状は認められなか った。MRIに执いては T2 強調像にて橋左側か ら右側正中にかけて辺縁不明瞭な高信号域を認め たが，T1 強調像では異常はみられなかった（図 $2,3)$ 。神経耳科学的検査では視標追跡検査 （ETT）にて saccadic pursuit そ，視運動性眼振 検査 (OKP) での緩徐相速度の低下及び眼振頻 度の低下を認めた。温度眼振検査では持続時間, 最大緩徐相速度とも左右差を認めなかった（図 4 )。以上の所見からめまいの原因は橋の虚血に よるものと診断し，血小板凝集抑制剂，脳微小循 環改善剂を投与, 2 週後には症状, 所見とも改善 した。

表 110 症例の概要

\begin{tabular}{|c|c|c|c|c|c|c|c|c|c|c|}
\hline 症例 & 年齢 & 性 & めまい & $\begin{array}{c}\text { M R I } \\
\text { 橋部高信号 }\end{array}$ & $\begin{array}{r}\text { M R I } \\
\text { テント上 }\end{array}$ & 眼 振 所 見 & $\mathrm{ETT}$ & O K P & 診 断 & \\
\hline 1 & 65 & 男 & 回 転 性 & 両 側 & + & 注視方向性眼振 & saccadic & 解発不良 & 中枢性 & \\
\hline 2 & 78 & 女 & 頭 位 性 & 両 側 & + & 垂直性頭位変換眼振 & saccadic & 解発不良 & 中枢性 & \\
\hline 3 & 60 & 男 & 頭 位 性 & 両 側 & + & 方向固定性頭位眼振 & smooth & 解発良好 & 末梢性 & C P $(+)$ \\
\hline 4 & 56 & 女 & 回 転 性 & 両 側 & + & 方向交代性下向性頭位眼振 & smooth & 左右差 (+) & 末梢性 & C P (+) \\
\hline 5 & 71 & 女 & 浮 動 感 & 両 側 & + & 方向固定性頭位眼振 & smooth & 左右差 $(+)$ & 末梢性 & $\mathrm{CP}(+)$ \\
\hline 6 & 68 & 女 & 回 転 性 & 両 側 & + & 方向交代性上向性頭位眼振 & saccadic & 解発不良 & 中枢性 & \\
\hline 7 & 61 & 男 & 頭 位 性 & 両 側 & + & 方向交代性下向性頭位眼振 & smooth & 解発良好 & 末梢性 & \\
\hline 8 & 69 & 女 & 回 転 性 & 片 側 & - & な L & smooth & 解発良好 & & \\
\hline 9 & 80 & 女 & 頭 位 性 & 片 側 & + & 水平回旋混合性自発眼振 & smooth & 解発良好 & 末梢性 & $\mathrm{CP}(+)$ \\
\hline 10 & 63 & 男 & 回 転 性 & 両 側 & + & 方向交代性上向性頭位眼振 & saccadic & 左右差 $(+)$ & 中枢性 & \\
\hline
\end{tabular}


Equilibrium Res Vol. 57(6)

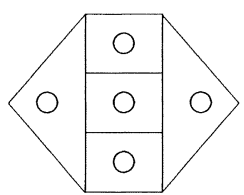

注 視

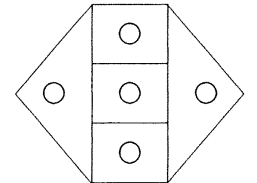

非 注 視

\begin{tabular}{|c|c|c|}
\hline$\Im$ & 0 & $\leftleftarrows$ \\
\hline$\Im$ & 0 & $\longleftarrow$ \\
\hline
\end{tabular}

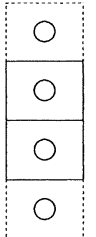

図 1 症例 No. 6 初診時眼振所見

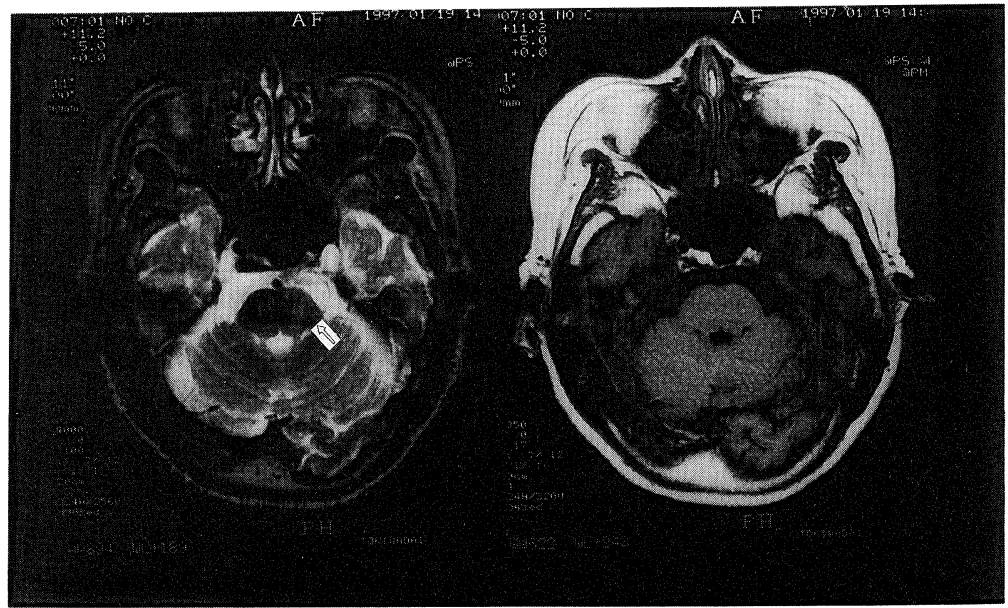

図 2 症例 No. 6 水平断 MRI

$\mathrm{T} 2$ 強調像にて橋左側から右側正中にかけて辺縁不明瞭な高信号域を認める。

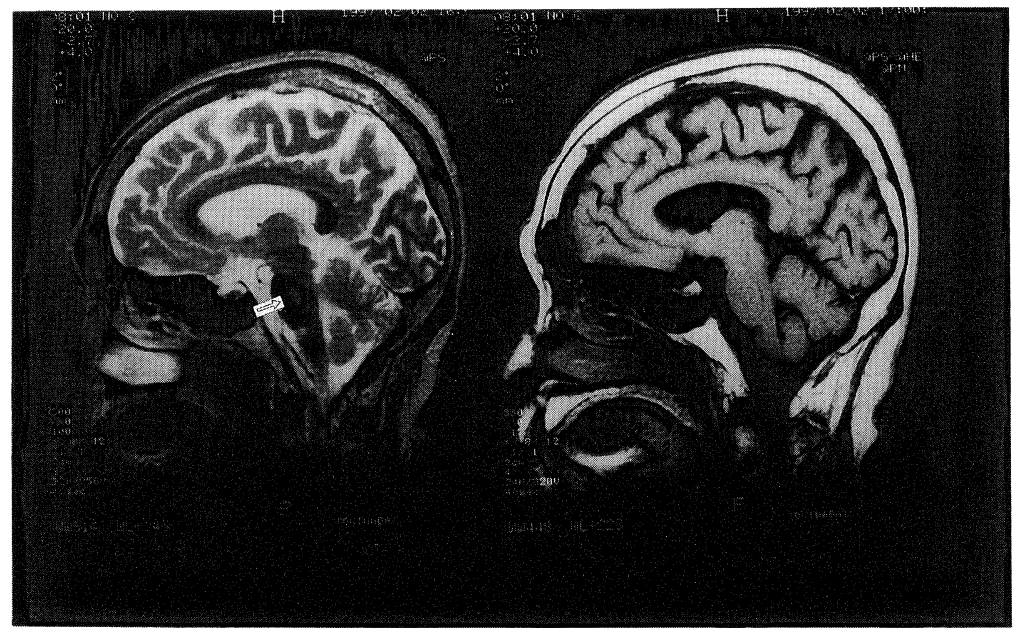

图 3 症例 No. 6 矢状断 MRI

$\mathrm{T} 2$ 強調像にて辺縁不明瞭な高信号域を認める。 


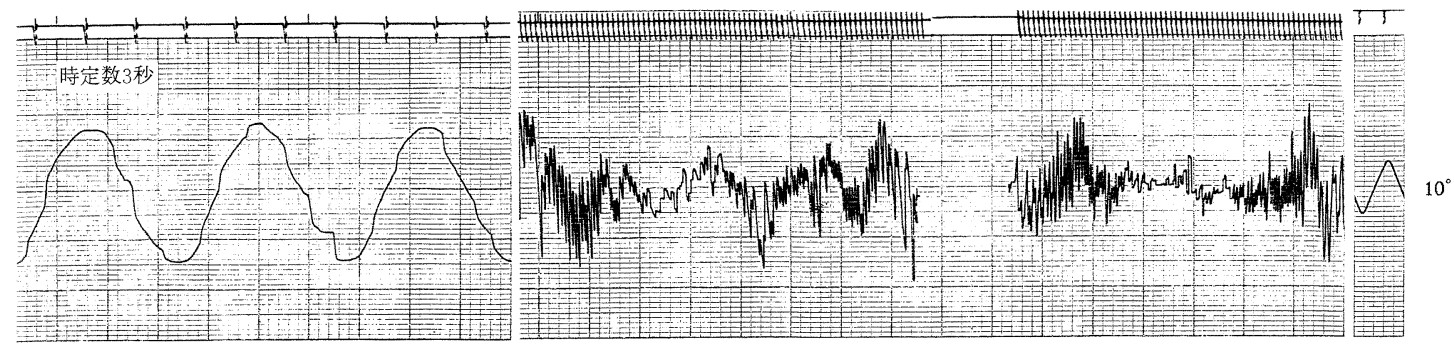

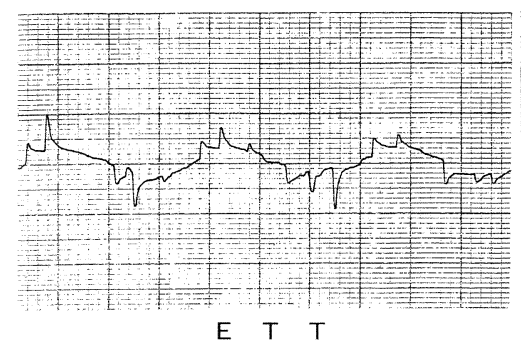

E $\quad T \quad T$

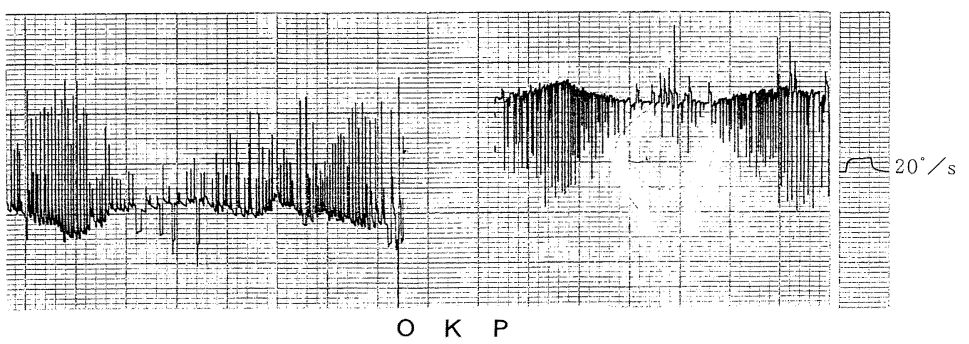

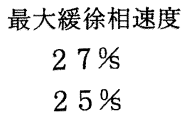

V. $\mathrm{S}$

$60 \%$

$60 \%$

図 4 症例 No. 6 ETT, OKP, 温度眼振検査

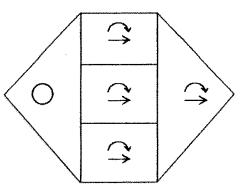

注 視

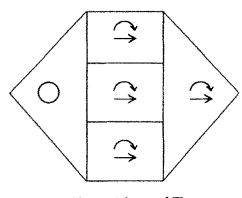

非 注 視
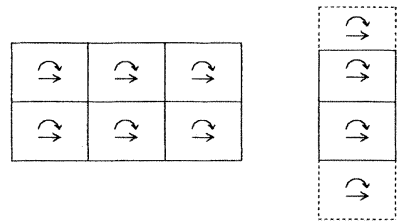

図 5 症例 No. 9 初診時眼振所見

症例 No. 9, 80 歳 女性

主訴 頭位性めまい

既往歴 肺腫瘍（扁平上皮癌）にて当院内科入 院加療中。

現病歴 平成 9 年 7 月 16 日朝，右側臥位にて回 転性めまいが出現するようになったが，左側臥位 では軽快する。蝸牛症状を含めて随伴症状はみら れなかった。

経過 同日当科依頼となり注視眼振検査にて左 向き水平回旋混合性の II 度眼振を認めた（図 5 ）。 MRI では T2 強調像にて橋左側に辺縁不明瞭な 高信号域を認めたが，T1 強調像では異常はみら れなかった（図 6 )。神経耳科学的検査では視標 追跡検査（ETT）にて年齢を考慮すれば正常パ
ターンであり, 視運動性眼振検査 (OKP) では 良好な眼振の解発を認めた。1 週後の温度眼振検 查にて右側の最大緩徐相速度の低下を認めた（図 7 )。

以上の所見より本症例のめまいの原因は右末梢 前庭障害によるものと考光, 初診時よりビタミン 鼡, 循環改善凧の投与を開始し, 2 週後には症状, 所見とも改善した。

\section{考察}

MRI での脳虚血性病変の検出には T2 強調像 がより鋭敏であるといわれている2。 ことに橋底 部は虚血に陥り易い部位であり，高龄者に执いて は T2 強調像にのみ異常信号を示す例も, 決して 稀ではないと報告されている3)。それだけにめま 
Equilibrium Res Vol. 57(6)

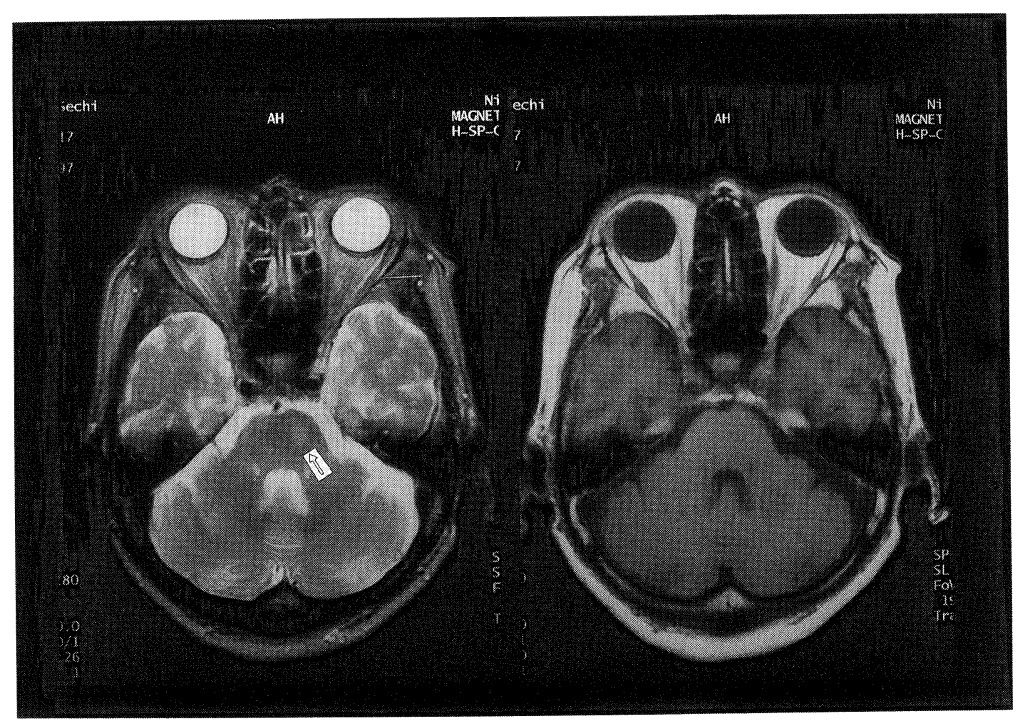

図 6 症例 No. 9 水平断 MRI

$\mathrm{T} 2$ 強調像にて橋左側に辺縁不明瞭な高信号域を認める。
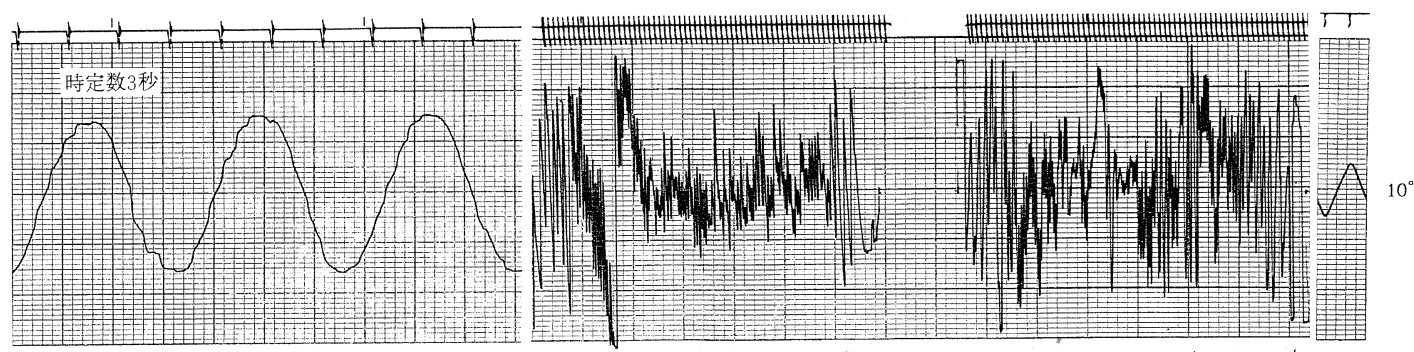

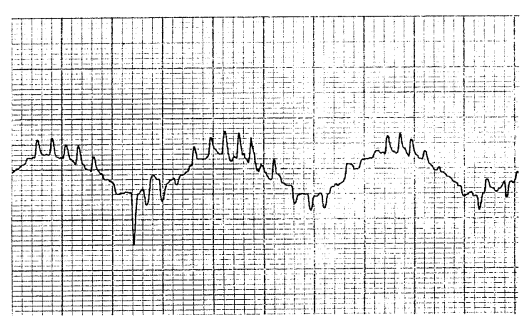

E T T

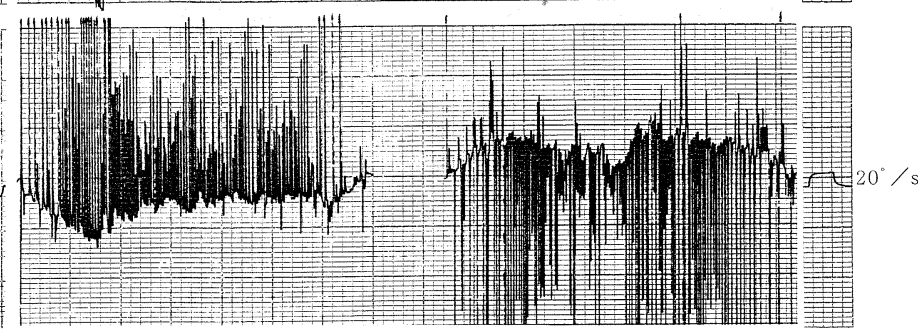

O $\quad K \quad P$

\begin{tabular}{|c|c|c|c|}
\hline & & & \\
\hline & 持 続 時 間 & 最大緩徐相速度 & \\
\hline 右 & $2^{\prime} 40$ & $15 \%$ & $70 \%$ \\
\hline 左 & $3^{\prime} 30$ & $35 \%$ & $65 \%$ \\
\hline
\end{tabular}

図 7 症例 No. 9 ETT, OKP, 温度眼振検査

いを主訴として受診し明らかな神経症候を伴わな い症例に括いては，MRI 上の異常信号を直ちに 原因と断定するべきではない。眼振所見, 神経耳
科学的検査から総合的に判断すると10例のうち 5 例のめまいの原因は末梢前庭障害と考光られ，め まいの診断に㧧いては神経耳科学的検討が不可欠 
なものと考えた。

MRI 上の高信号域は CT での Leukoaraiosis と同質の異常と考兄られている4)。これは病理学 的には gliosis を伴った軸索や髄鞘の消失，小梗 塞巣などが混然とした状態であり，gliosisによ る水分の増加及び細胞外スペースの拡張によって 高信号を呈する5)。すなわち虚血の程度が梗塞よ り軽度の状態と考兄られている。このような異常 が橋に生じやすい原因としては，解剖学的な特殊 性によるのではないかと推測される。

脳幹内部を栄養する動脈は脳底動脈や椎骨動脈 からの脳幹穿通枝及び AICA や PICA から分岐 する脳幹外側回旋枝からの穿通枝である6)。橋は 径が大きいためにとれらの動脈は最も長く, 動脈 硬化性変化が進行すると橋の中心部分が最も虚血 を起こしやすいと考えられている7)

MRI 上橋部高信号の特徵としては辺縁が不明 瞭で両側性にみられることが多く, テント上にも 高信号が高頻度に合併しやすいと報告されている 3)8)。今回の検討でも全例とも辺縁が不明瞭であ り, 8 例が両側性に認められた。テント上の高信 号の合併も 9 例にみられており, 動脈硬化がテン ト上にも進行していると考光られた。また末梢性 と考光られる症例に拈いても, めまいの原因とし ては動脈硬化に起因する末梢前庭系への循環障害 が根底にあるものと考兄られる。橋部高信号を合 併しない末梢前庭障害（前庭神経炎等）と比較す ると, めまいを繰り返す例（症例 No. 3, 4） や眼 振所見が持続する傾向があり, 長期的な治療, 経 過観察が必要ではないかと考える。

MRI 上の高信号は虚血の程度が梗塞より軽く, 可逆的要素も存在すると考光られている1)。しか し治療によって高信号が消失するか否かは今後さ らに検討が必要である。

\section{まとめ}

1. MRI 上橋部高信号を呈した10症例につい て神経耳科学的に検討したところ，めまいの原因 が橋の虚血と考光られた中枢性の症例は 4 例であ り，末梢前庭障害と考えられた症例は 5 例であっ た。1例は異常所見がなくめまいの原因を特定で
きなかった。

2. MRI にて橋に高信号を認める症例に打い てはめまいの原因は橋以外にあることも少なくな いので, 診断に際しては神経耳科学的検討は不可 欠なものと考える。

本論文の要旨は, 第56回日本平衡神経科学会総 会（平成 9 年10月, 松本）に拈いて口演した。

\section{文献}

1 ) 渡辺正樹, 高橋 昭, 新畑 豊, 他 : MRI 上橋部高信号の臨床的意義. 臨神経 33: 721 $-725,1993$

2 ) Bryan RN, Willcott MR: Nuclear magnetic resonance evaluation of stroke. A preliminary report. Radiology 149: 189-198, 1983

3 ) 丹野宗彦 : 高齢者脳 MRI で脳幹部とくに橋 部に異常信号を示した症例について．日老医 会誌 29: 190-197, 1992

4 ) Kobari M, Meyer JS: Leukoaraiosis: Correlation of $\mathrm{MR}$ and $\mathrm{CT}$ findings with blood flow, atrophy, and cognition. AJNR 11: 273281, 1990

5 ) Revesz T, Hawkins CP: Pathological findings correlated with magnetic resonance imaging in subcortical arteriosclerotic encephalopathy (Binswangers disease). J Neurol Neurosurg Psychiatry 52: 1337-1344, 1989

6 ）松永 喬: 椎骨脳底動脈循環動態とめまい。 第96回日本耳鼻咽喉科学会宿題報告. $2-5$ 頁, 1995

7 ) 内野 晃, 小野村健太郎, 大野正人 : 脳幹梗 塞の MRI．臨放線 34: 313-316, 1989

8 ) 渡辺正樹, 高橋 昭, 新畑 豊, 他 : 橋部高 信号例の MRI および MR angiography 所 見. 耳鼻 39: 757-762, 1993

\footnotetext{
$\left(\begin{array}{l}\text { 原稿到着: 平成 } 10 \text { 年 } 5 \text { 月 } 8 \text { 日 } \\ \text { 別刷請求先 : 吉田晋也 } \\ \text { 个173- } 8610 \text { 東京都板橋区大谷口上町 } 30-1 \\ \text { 日本大学医学部耳鼻咽喉科学教室 }\end{array}\right)$
} 